\section{MALLARD SURVIVES MANDIBLE INJURY}

by R. W. Nero, Saskatchewan Museum of Natural History

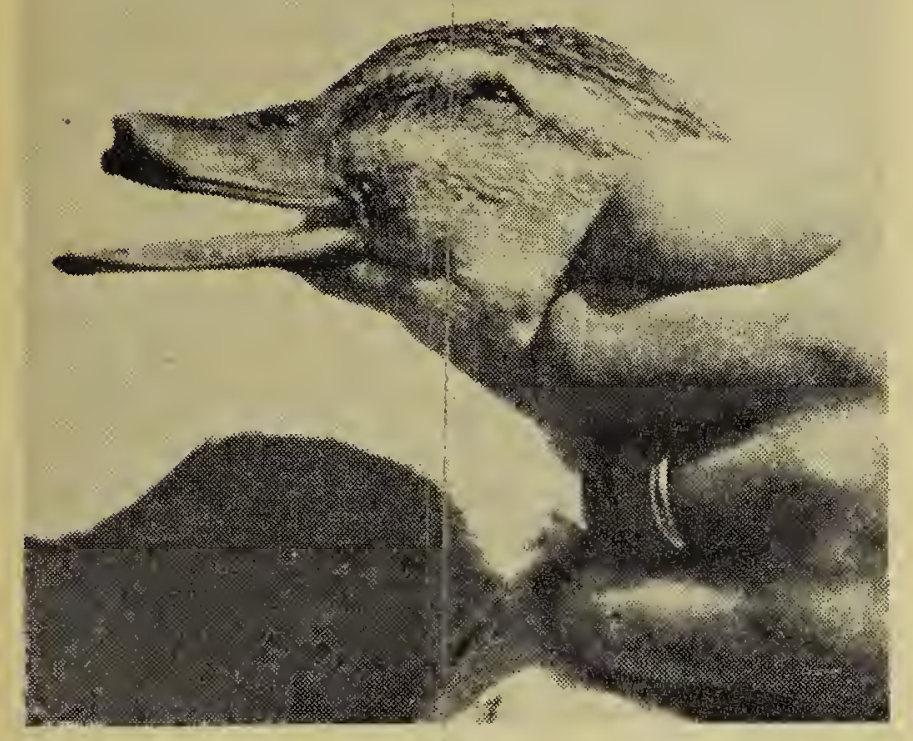

In early May, 1955, while collecting ducks near Madison, Wisconsin, for the University of Wisconsin Zoology Department, I shot a hen Mallard which had survived in spite of an extensive injury to the upper mandible (see photo). More than an inch of the end of the bill had been removed as neatly as if with a knife. The wellrounded edges of the shortened bill suggested that the injury had been sustained soms time before. It seems most likely that the bird had been injured during the previcus hunting season. Surprisingly, the bird was very fat and heavy and was evidently managing well. It was collected in flight while returning from feeding in a wet and muddy corn field and its crop was filled with kernels of corn and earthworms. The duck was apparently able to manipulate these small and slippery items with the sides of the remaining bill structure.

\section{INTERESTING AMERICAN WIDGEON RECOVERY}

An American Widgeon banded by Stuart Houston at Yorkton, Sask., Aug. 28, 1943 (the first week of his banding activities) was shot Feb. 18, 1955, twenty miles east. of Navagoa, Mexico. This duck was nearly 12 years old when shot, a near record for this species. The band number had to be deciphered by chemical etching.-C.S.H.

\section{MALLARD GOES NORTH AFTER NESTING}

\author{
by J. B. Gollop, Canadian Wildlife \\ Service, Saskatoon
}

On May 17, 1957, a Canadian Wildlife Service crew flushed a hen Mallard off her nest of nine eggs, twelve miles southwest of Kindersley, Sask. On May 28 the bird was trapped, banded and marked with a red and white plastic neckband as part of a re-nesting and brood-movement study. The clutch hatched between June 3-10 as evidenced by subsequent checking by Alex Dzubin and the finding of egg-membranes in the nest on the latter date. The hen was not reported during the remainder of the summer on or in the vicinity of the 80-acre slough beside which her eggs had hatched, so we do not know for sure that she successfully raised a brood.

On Oct. 2, 1957, this hen was shot, with neckband intact, on the Embarras River between Lakes Athabaska and Claire in northern Alberta. The straight-line distance is 500 miles to the north-northwest.

\section{BLUE JAY FROM NEBRASKA}

by Stuart Houston, Yorkton

Everyone is aware of the long journeys made twice yearly by our migratory birds. Less well appreciated, however, is the fact that individuals of species present with us all year round may still make extensive journeys of a wandering nature.

Lorne Prouse, of Kelvington, Saskatchewan, found a Blue Jay in his barn about November 1, 1959. It seemed weak and could not fly well, so he took it into his house. Next morning it was dead. It was wearing band number 583-54961, which was submitted to Dr. Stuart Houston, who forwarded it to Washington. It was fully expected that it would prove to have been banded by some of our Saskatchewan banders, probably by the Hoopers at Somme or by Street at Nipawin. Imagine our surprise to learn that this bird had been banded at Wisner, Nebraska, on October 25, 1958, some 760 miles distant, by that enthusiastic bander, Mrs. John Lueshen, whom we met at the A.O.U. meeting in Regina last August. 